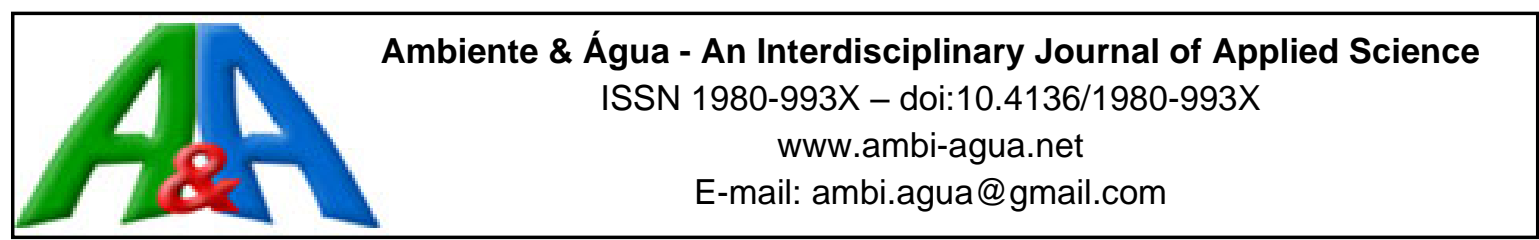

\title{
Permanent preservation areas in Mantiqueira sierra: perspectives for regularization along watercourses
}

\author{
ARTICLES doi:10.4136/ambi-agua.2422
}

Received: 11 Jun. 2019; Accepted: 25 Nov. 2019

\section{Leandro Henrique Leite ${ }^{1(D ;}$; Vanessa Cabral Costa de Barros $^{2}{ }^{(D}$; Maria Eduarda Carvalho Monteiro ${ }^{3}$; Luiz Otávio Moras Filho ${ }^{2 *}$; Luís Antônio Coimbra Borges ${ }^{2}$ iD}

\footnotetext{
${ }^{1}$ Departamento de Ciências Florestais. Laboratório de Ecologia Florestal. Universidade Federal de Lavras (UFLA), Aquenta Sol, CEP: 37200-000, Lavras, MG, Brazil. E-mail: leandro.leite@ outlook.com.br ${ }^{2}$ Departamento de Ciências Florestais. Setor de Conservação da Natureza. Universidade Federal de Lavras (UFLA), Aquenta Sol, CEP: 37200-000, Lavras, MG, Brazil. E-mail: vanessacabralcb@gmail.com, luis.borges@ufla.br

${ }^{3}$ Departamento de Ciências do Solo. Universidade Federal de Lavras (UFLA), Aquenta Sol, CEP: 37200-000, Lavras, MG, Brazil. E-mail: mecmonteiro@yahoo.com.br *Corresponding author. E-mail: lomf22@gmail.com
}

\section{ABSTRACT}

Brazilian Native Vegetation Protection Law (Law n. 12.651/2012) brought flexibility related to the sizing of Permanent Preservation Areas (PPAs) along watercourses when there was anthropogenic occupation before July 22, 2008 (consolidated rural area), which may vary according to the size of the property. To better understand the effects of this law, we analyzed land use and land occupation in PPAs along watercourses in a portion of Grande River drainage basin. Scenarios were also developed to compare the effects of the reduction of PPA limits, allowing us to discuss measures to avoid water quality deterioration. We obtained the drainage network and individualized the study area through images available in Google Earth ${ }^{\mathrm{TM}}$, and we extracted information about land use and land occupation from a vector provided by the Laboratory of Studies and Projects in Forest Management from Federal University of Lavras. Recovery scenarios were estimated according to Article n. 61-A from the Native Vegetation Protection Law. There was a significant reduction of environmental liability compared to previous legislation. In the more restrictive scenario, there may be a $31 \%$ deficit in recovery areas, where watersheds with a strong presence of small rural properties will be the most affected. Although the reduction of recovery areas is characterized as a retrogression in the protection of native vegetation, complementary strategies could be implemented, such as economic incentive mechanisms.

Keywords: native vegetation protection law, water management, watershed management.

\section{Áreas de preservação permanente na serra da Mantiqueira: perspectivas de regularização ao longo dos cursos d'água}

\section{RESUMO}

A Lei de Proteção da Vegetação Nativa (Lei no 12.651/2012) trouxe uma flexibilidade relacionada ao dimensionamento de Áreas de Preservação Permanente (APPs) ao longo dos 
cursos d'água em razão de ocupação antrópica preexistente a 22 de julho de 2008 (área rural consolidada), que pode variar de acordo com o tamanho do imóvel rural. Para melhor compreender os efeitos dessa lei, analisamos o uso e a ocupação da terra em APPs ao longo de cursos d'água em uma porção da bacia do Rio Grande. Também elaboramos cenários para comparar os efeitos da redução de limites de APPs, discutindo medidas para evitar degradação da água. Extraímos a rede de drenagem e individualizamos a área de estudo com auxílio de imagens disponíveis no Google Earth ${ }^{\mathrm{TM}}$, e extraímos informações sobre o uso e ocupação da terra a partir de um vetor fornecido pelo Laboratório de Estudos e Projetos em Manejo Florestal da Universidade Federal de Lavras. Os cenários de recuperação foram estimados de acordo com o artigo n. 61-A da Lei de Proteção da Vegetação Nativa. Houve redução significativa do passivo ambiental em comparação com a legislação anterior. No cenário mais restritivo, pode haver um déficit de $31 \%$ nas áreas de recuperação, onde as bacias com forte presença de pequenos imóveis rurais serão as mais afetadas. Embora a redução das áreas de recuperação seja caracterizada como um retrocesso na proteção da vegetação nativa, estratégias complementares podem ser implementadas, como mecanismos de incentivo econômico.

Palavras-chave: gestão da água, lei de proteção da vegetação nativa, manejo de bacias hidrográficas.

\section{INTRODUCTION}

Watersheds are territorial units defined by the terrain, where part of the precipitated water flows to the same point, called the "control section". Downstream of the watershed, land use and land occupation directly influence water quality (Rodríguez-Romero et al., 2018) and, in order to ensure the conservation of watercourses, the Brazilian government enacted the National Water Resources Policy (Law n. 9,433/1997). This law enshrines the watershed as a planning unit as well as for the management of water resources, requiring the adoption of conservation practices in all its extensions.

The drainage network margins play an important role in water-resource conservation by acting on slope stabilization, channel maintenance, sediment containment, siltation prevention, and soil permeability maintenance (Zaimes et al., 2019). In order to ensure these functions, the Brazilian government established through the Native Vegetation Protection Law (Law n. 12,651/2012) minimum ranges that should be kept as "Permanent Preservation Areas" (PPAs).

According to the fourth article of Native Vegetation Protection Law, it is mandatory to preserve a marginal area along watercourses, which should vary according to the watercourse width. The gutter edge of the regular riverbed is taken as a reference for measuring the width of this PPA category. However, transitional provisions for vegetation recovery were established through Article n. 61-A, of this same law in areas that had been anthropized before July 22, 2008 (enactment date of Federal Decree n. 6,514/2008), called "consolidated rural areas". According to this transitional provision, when a consolidated rural area overlaps a PPA, the marginal area will vary according to the property size - measured in Fiscal Modules (FM), rather than due to the watercourse width. This provision is known as the "ladder rule".

In order to better comprehend the effects of the article 61-A, we analyzed land use and land occupation of PPAs along watercourses in Grande River Basin, a strategic watershed in Brazil for water supply and hydroelectric power generation (Viola et al., 2014). We also elaborate scenarios to compare the effects of PPAs limit reductions, allowing us to discuss measures to avoid water degradation. 


\section{MATERIALS AND METHOD}

\subsection{Description of the study area}

The area selected for analysis of recovery scenarios resulting from Law n. 12.651/2012 is located in Grande River Basin, in the cities of Itanhandu and Passa Quatro, Minas Gerais state. This region covers the springs of the Verde River, an important tributary of Grande River. We entitled the study area "Sub-Basin of Verde River Springs" (SBVRS), presented in Figure 1. The study area is geographically positioned between the coordinates $22^{\circ} 25^{\prime} 59.148^{\prime \prime} \mathrm{S}$, $44^{\circ} 48^{\prime} 12.517^{\prime \prime} \mathrm{W}$ and $22^{\circ} 17^{\prime} 23.435^{\prime \prime} \mathrm{S}, 44^{\circ} 55^{\prime} 52.356^{\prime \prime} \mathrm{W}$, with approximately $12 \mathrm{~km}^{2}$. The control section of the watershed is defined by coordinates $22^{\circ} 17^{\prime} 55.246^{\prime \prime} \mathrm{S}$ and 44 55'35.284" W, located in Itanhandu.

The terrain is characterized by steep hills, steep slopes, shallow soils, and embedded valleys (Minas Gerais Institute of Water Management, 2010). The climate is described as subtropical highland, with dry winter and mild summer (Cwb) (Alvares et al., 2013). Regarding precipitation, the average annual rainfall in Itanhandu is approximately $1404 \mathrm{~mm}$ (Minas Gerais Institute of Water Management, 2010). In the study area, there is a great variation in average annual precipitation and the values vary from $1,500 \mathrm{~mm}$ in the northern region to $2,000 \mathrm{~mm}$ in the southern region. The variation of precipitation follows the altitudinal variation of the area, where the lower the altitude, the lower the precipitation (Pinto et al., 2011).

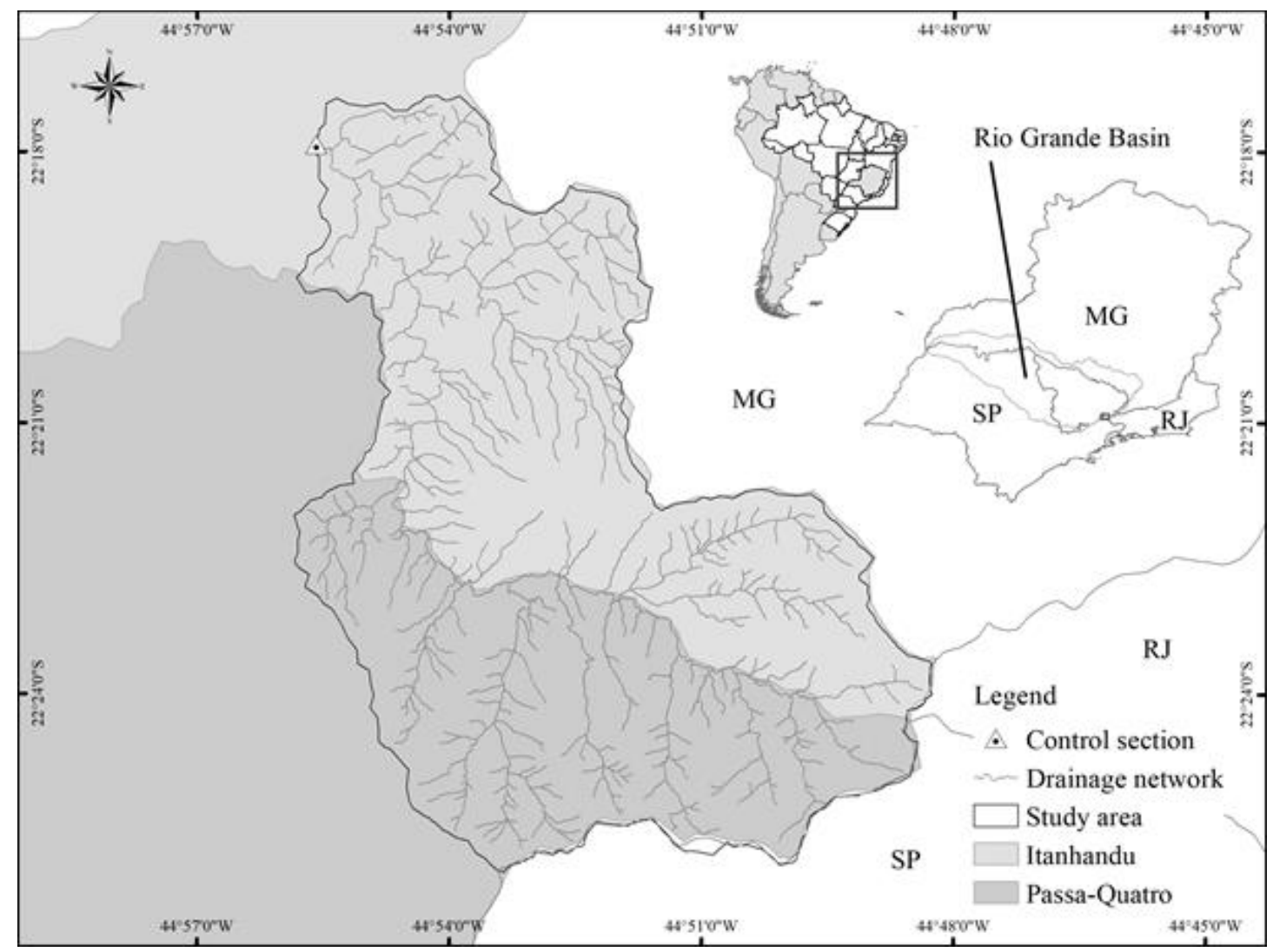

Figure 1. Study area location: the Sub-Basin of Verde River Springs.

Regarding local soil morphology, the predominant occurrence is typical dystrophic red agrisoil, both in the lower and flat portions as well as in higher steep regions. The typical dystrophic humic cambisol also occurs, but is restricted to the higher and embossed regions presenting larger declivities.

According to Brazilian morphoclimatic domains, the study area is part of the forested "Mares de Morros" domain, popularly known as "Atlantic forest". The native vegetation that 
occurs in the study area is distributed between grassy and forest formations. The native vegetation cover is mainly concentrated in the higher regions and associated with watercourses (Oliveira-Filho et al., 2006). The study area fits into a context considered highly rich in endemic, rare and endangered species, being considered a biodiversity hotspot and one of the irreplaceable areas for world biodiversity conservation (Gonzaga, 2019).

\subsection{Database and GIS procedures}

In order to outline the study area, we identified the direction of surface runoff through altitude information contained in a file provided by the Earth Data project of the National Aeronautics and Space Administration (NASA), with a spatial resolution of 12.5 meters, based on the digital elevation model of the ALOS sensor. With this information, it was possible to recognize the entire contribution area of the sub-basin.

Due to watercourses in the study area being narrow and smaller than the spatial resolution of the Landsat 8 images, we obtained the drainage network manually. We've used the images available in Google Earth ${ }^{\mathrm{TM}}$ as a reference to help identify the hydrography. Google Earth ${ }^{\mathrm{TM}}$, in addition to higher spatial resolution images, features a tilt profile that guides the identification of possible water runoff channels. The manual process was based on the identification of patterns that correspond to the probable existence of watercourses, such as image texture, presence of vegetation, terrain, and color. With this information, it was possible to draw PPAs along watercourses and demarcate recovery areas with the support of a Geographic Information System (GIS).

The Laboratory of Studies and Projects in Forest Management from Federal University of Lavras (acronym in Portuguese LEMAF/UFLA) provided information about land use and land occupation. They used an image obtained from the Rapid Eye sensor from 2012, with 5 meters of spatial resolution. The raster file was generated using the object-oriented supervised classification method GEOBIA (Geographic Object-Based Image Analysis), besides the classification algorithm called 50 SVM (Support Vector Machine).

The limits of the existing properties in Itanhandu and Passa Quatro were obtained from the public consultation tab of Rural-Environmental Registry website (acronym in Portuguese CAR). To identify and quantify the properties that overlap with SBVRS, we used a GIS environment.

\subsection{Analysis of Native Vegetation Protection Law}

For the delimitation of the PPAs along watercourses in the study area, according to the fourth article from Native Vegetation Protection Law, the planimetric distance of 30 meters in each margin was established. We adopted this distance as a criterion assuming that all watercourses have their regular riverbed width less than 10 meters, which is consistent with the reality of the watershed terrain.

As for recovery scenarios, according to Article 61-A from Native Vegetation Protection Law, the same method of generating PPAs was used, changing only the reference widths (Table 1 ), where the areas of the different features of land use and occupation were quantified.

Table 1. Recovery areas according to the Article 61-A from native vegetation protection law.

\begin{tabular}{cccc}
\hline Scenarios & Property Size (FM) & Property Area (ha) & Recovery Area (m) \\
\hline 1 & $0 \mathrm{a} \leq 1$ & $\leq 30$ & 5 \\
2 & $>1 \mathrm{a} \leq 2$ & $>30 \mathrm{a} \leq 60$ & 8 \\
3 & $>2 \mathrm{a} \leq 4$ & $>60 \mathrm{a} \leq 120$ & 15 \\
4 & $>4$ & $>120$ & 30 \\
\hline
\end{tabular}


For properties with an area superior to four FM, the recovery area must vary between 20 and 100 meters in planimetric projection, according to Environmental Regularization Program. In this situation, we assumed a recovery area of 30 meters, since the database from Environmental Regularization Program is not available.

\section{RESULTS AND DISCUSSION}

\subsection{Land use and land occupation}

We have identified four physiognomies related to land use and land occupation in the study area: "Native Vegetation", "Anthropic Use", "Urbanization", and "Water". Those physiognomies are represented and quantified in Figure 2.

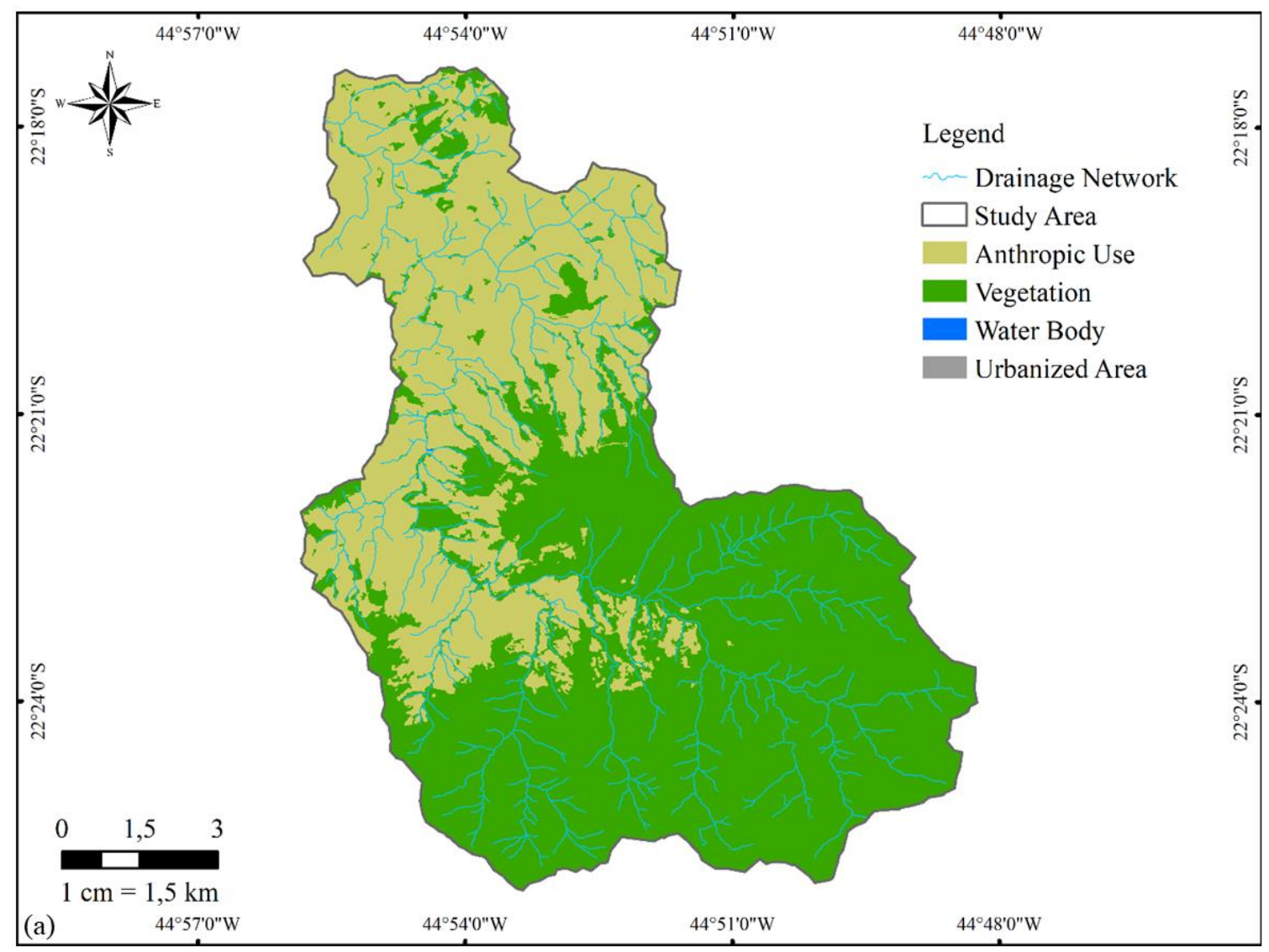

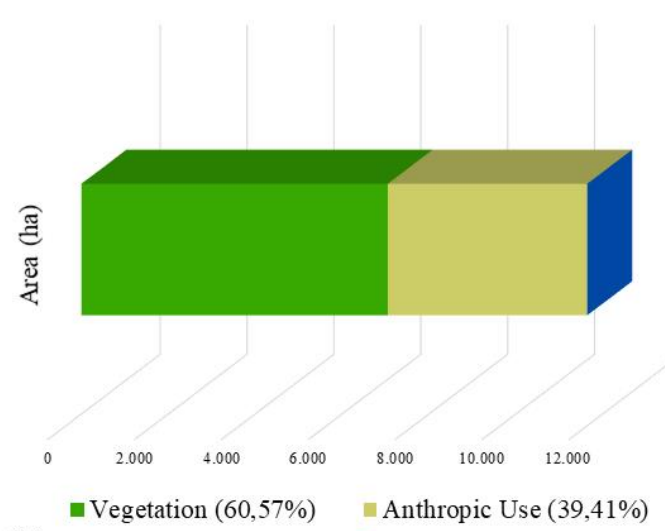

(b) $\backsim$ Urbanized Area $(0,02 \%) \backsim$ Water Body $(0,01 \%)$

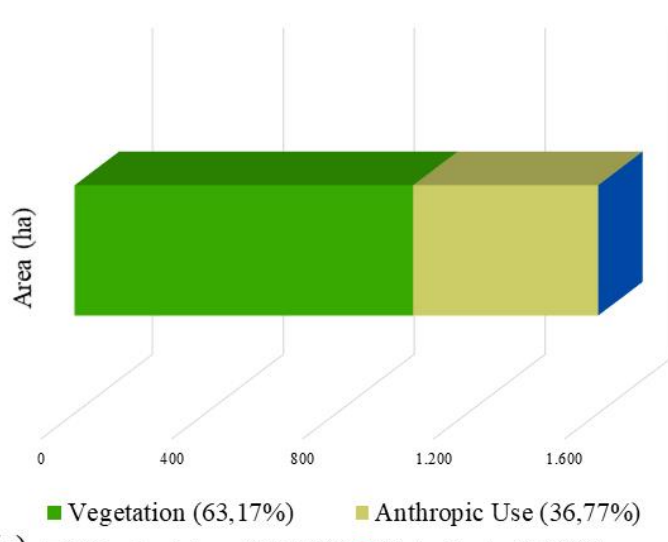

(c) $=$ Urbanized Area $(<0,01 \%)$ " Water Body $(0,06 \%)$

Figure 2. Land use and land occupation in (a) the study area: (b) area (ha) and percentage of each physiognomy identified in the study area, and (c) area (ha) and percentage of each physiognomy identified in PPAs along watercourses. 
Nearly $60.6 \%$ of the total sub-basin area is covered by native vegetation, which occurs predominantly at altitudes above $1,100 \mathrm{~m}$ in Itanhandu, on the right bank of the Verde River, and above 1,400 $\mathrm{m}$ in Passa Quatro. We can infer that these areas were maintained due to the difficulty in managing, establishing crops or infrastructures. In both cities, native vegetation was associated with the presence of watercourses, which reflects legal impositions prior to Law n. 12.651/2012.

Regarding PPAs, almost $37 \%$ of the area is not covered by native vegetation, according to the limits fixed by the fourth article of Native Vegetation Protection Law. Most of PPAs are situated in upper portions of the study area, where the springs that supply Verde River are located. The "Anthropic Use" category occurs more expressively in the lower portions. A higher absence of native vegetation in PPAs has been located in the higher portions of Passa Quatro, near Lamins and Paiolinho communities.

\subsection{The influence of properties size}

Considering the self-reported data in Brazilian Rural-Environmental Registry, we have identified properties in the four proposed categories, with predominance of small rural properties (Figure 3). There is a decrease in number in the categories comprising properties with larger areas. This pattern has occurred in the distribution analysis of registered properties for cities in the study area. Among the 1,345 rural properties that were registered in Itanhandu and Passa Quatro, 202 rural properties are situated in the study area. In this sub-basin, among $97 \%$ of rural properties are smaller than four fiscal modules.
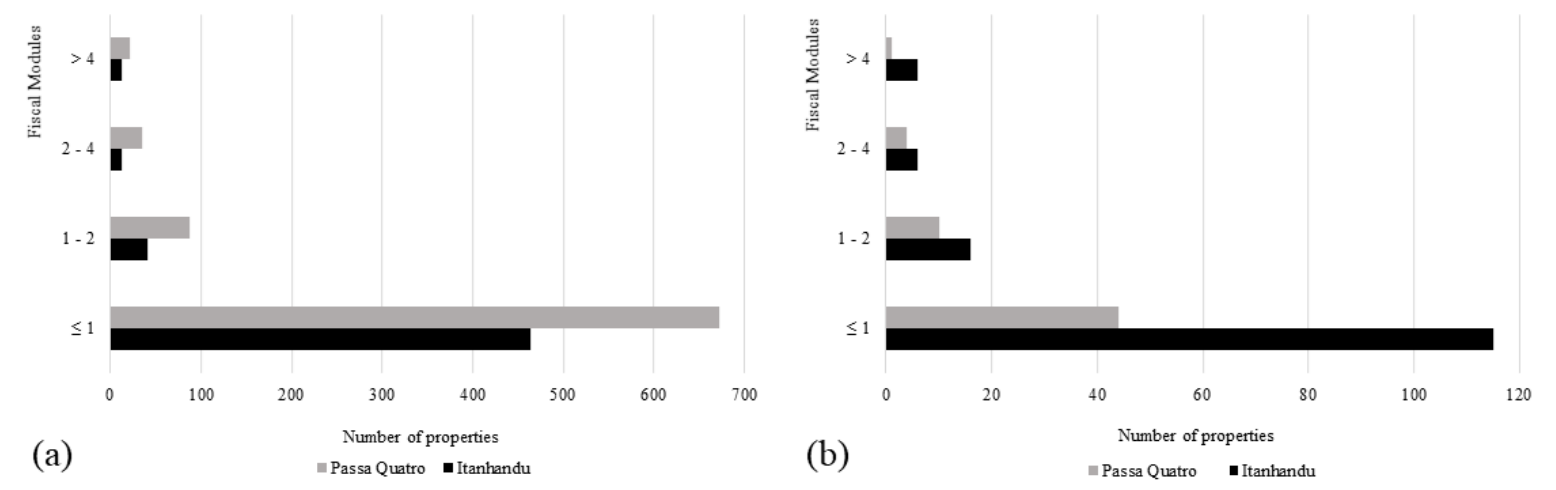

Figure 3. Number of rural properties by Fiscal Modules in (a) Itanhandu and Passa Quatro, and in (b) the study area.

In Brazilian Rural-Environmental Registry, property boundary information is registered through a self-declaration process. Therefore, owners, squatters or people who have some kind of link with the property can carry it out. However, considering that the registration platform is not intuitive for those unaware of environmental legislation, photo interpretation, and geoprocessing tools, as expected, there was a large amount of overlapping property boundaries. Consequences of this overlap does not reach land regularization scope, since information inserted in Brazilian Rural-Environmental Registry is valid only to know the environmental reality of rural properties in the country, aiming at environmental regularization. However, this process implies possible errors in property sizing and, consequently, errors in the sizing of recovery areas (Article n. 61-A from Native Vegetation Protection Law).

Although there is no reliable database containing the real properties boundary for the study area, we have identified a tendency of property distribution that corresponds to Brazilian reality. Brazilian territory presents a land profile that is comprised of a few properties with large areas, many small properties and a high number of overlaps (Sparovek et al., 2019). 


\subsection{Perspectives for regularization}

Due to spatial resolution limitation, polyline vector files have been used to outline both PPA and recovery areas, since we do not have geographic information to spatialize watercourses widths. Although unconventional, polyline vector files have been reported in literature as a suitable technique to simulate PPA limits (Alvarenga et al., 2017; Rosot et al., 2018; Rodríguez-Romero et al., 2018; Valera et al., 2019).

When comparing the proposed areas in Article 61-A of Native Vegetation Protection Law, a great variation of area to be recovered was detected (Table 2).

Table 2. Recovery scenarios in the study area.

\begin{tabular}{ccccccc}
\hline Scenario & $\begin{array}{c}\text { Property } \\
\text { Area (FM) }\end{array}$ & $\begin{array}{c}\text { Recovery } \\
\text { Area }(\mathbf{m})\end{array}$ & $\begin{array}{c}\text { Recovery } \\
\text { Area (ha) }\end{array}$ & $\begin{array}{c}* \text { Recovery } \\
\text { percentage (\%) }\end{array}$ & $\begin{array}{c}* \text { Recovery } \\
\text { Deficit (ha) }\end{array}$ & $\begin{array}{c}\text { Recovery Deficit } \\
\text { in PPAs (\%) }\end{array}$ \\
\hline 1 & $\leq 1$ & 5 & 94.97 & 16 & 508.15 & 31 \\
2 & $>1$ and $\leq 2$ & 8 & 152.25 & 25 & 450.87 & 28 \\
3 & $>2$ and $\leq 4$ & 15 & 288.66 & 48 & 314.46 & 19 \\
4 & $>4$ & 30 & 603.12 & 100 & 0.00 & 0 \\
\hline
\end{tabular}

* Related to Scenario 4 (total recovery).

In Scenario 1, only $16 \%$ of PPAs would be recovered. In Scenarios 2 and 3, we predict that, respectively, nearly 25 and $48 \%$ of PPAs would be recovered. If the limits of the fourth article from Native Vegetation Protection Law was maintained (Scenario 4), 603.12 ha of native vegetation would be recovered. PPAs recovery deficit was larger in the first scenario, which is worrying since the study area is characterized mostly by small, fragmented properties. Regions where intensive activities are developed and, consequently, have lower rates of native vegetation cover, with a strong presence of small rural properties, will be the most affected by this flexibility.

Clearly, the 2012 change in environmental legislation will lead to a reduction in areas to be recovered. This reduction is estimated to be $4.5 \pm 1$ million hectares (Soares-Filho, 2014; Guidotti et al., 2017), an area larger than Denmark, Holland, or Switzerland, and also larger than Rio de Janeiro, Alagoas, or Sergipe state.

In a study carried out in a micro basin located inside our study area, Monteiro et al. (2017) presented how property size influences the recovery strings according to rticle 61-A. Nearly $90 \%$ of properties was characterized as small, being more affected by legislation changes. Environmental liability in PPAs along watercourses in this microbasin was estimated among $68 \%$ and, with this flexibilization, could be reduced to $20 \%$. Borges et al. (2017) found in their studies in Pandeiros and Calindó River Basins that $95 \%$ of properties registered in Brazilian Rural-Environmental Registry are smaller than 4 fiscal modules and will be the most affected by the "ladder rule". This value is close to the 90\% identified by Soares-Filho (2014) for Brazil. Our study presents a close percentage to the above-mentioned (almost 97\%).

Native vegetation around watercourses plays an important role in maintaining water quantity and quality. PPAs act as an interface between terrestrial and aquatic ecosystems and can be a source or filter of sediments available in the environment. Apparently, the width of vegetated range acts as a "thermometer" indicating the function exerted by PPA. In general, these areas act as filters when the preserved range is larger than 15 meters and as sources when the ranges are smaller. Land use and the adoption of good agricultural practices also contribute to determining the range required for PPAs to act as filters or sediment sources (Guidotti et al., 2017).

PPAs along watercourses are important in terms of solar energy transfer to the aquatic environment, interception of nutrients and sediment entering rivers, and exchange of organic material between terrestrial and aquatic systems (Pusey and Arthington, 2003). They play multiple roles including "land tenure, water protection, and wildlife conservation", and act as 
ecological corridors that facilitate flow of individuals into the landscape. Their benefits are related to factors such as width, topography, extent, continuity, and quality. Among these factors, the width is the most important, as it influences the relationship between interior and border, as well as microclimatic changes. The minimum width of PPAs along watercourses should be 100 meters (50 meters on each bank), regardless of biome, taxonomic group, soil class, or topography (Metzger, 2010).

Currently, vegetation recovery in PPAs along watercourses is generally established by command and control actions, such as the Native Vegetation Protection Law. However, the existence of a legislation itself does not guarantee that the vegetation deficit will be recovered, as there were liabilities concerning previous legislation (Guidotti et al. 2016; 2017). To support legislation compliance, it is necessary to implement complementary strategies, such as economic incentive mechanisms.

\section{CONCLUSIONS}

Watersheds with a strong presence of small rural properties will be the most affected by the flexibility brought by Article 61-A, which could compromise the functionality of PPAs along watercourses.

With the support of the four scenarios built in this study, we verified that there was a significant reduction of environmental liability compared to previous legislation. In the more restrictive scenario, there may be a $31 \%$ deficit in recovery areas.

Although the reduction of recovery areas is characterized as a retrogression in the protection of native vegetation, complementary strategies could be implemented, such as economic incentive mechanisms.

\section{ACKNOWLEDGEMENTS}

To the Foundation for Research of the State of Minas Gerais (FAPEMIG), and to the Coordination for the Improvement of Higher Education Personnel (CAPES).

\section{REFERENCES}

AlVARENGA, L. A.; MELlo, C. R. de; COLOMBO, A.; CUARTAS, L. A. Hydrologic impacts due to the changes in riparian buffer in a headwater watershed. Cerne, v. 23, n. 1, p. 95-102, 2017. http://dx.doi.org/10.1590/01047760201723012205

ALVARES, C. A.; STAPE, J. L.; SENTELHAS, P. C.; GONÇALVES, J. L. M.; SPAROVEK, G. Köppen's climate classification map for Brazil. Meteorologische Zeitschrift, v. 22, p. 711-728, 2013. https://doi.org/10.1127/0941-2948/2013/0507

BORGES, L. A. C.; MORAS FILHO, L. O.; MARQUES, R. T.; DA SILVA, C. C.; DE PAULA SILVA, L. G. A influência do tamanho do imóvel rural sobre as áreas de preservação permanente de corpos d'água. Caminhos de Geografia, v. 18, n. 64, p. 444-453, 2017.

GONZAGA, D. R.; PEIXOTO, A. L.; MENINI NETO, L. Patterns of richness and distribution of Cactaceae in the Serra da Mantiqueira, Southeast Brazil, and implications for its conservation. Acta Botanica Brasilica, v. 33, n. 1, p. 97-105, 2019. http://dx.doi.org/10.1590/0102-33062018abb0178

GUIDOTTI, V.; FREITAS, F. L.; SPAROVEK, G.; PINTO, L. F. G.; HAMAMURA, C.; CARVALHO, T.; CERIGNONI, F. Números detalhados do Novo Código Florestal e suas implicações para os PRAs. Sustentabilidade em Debate, v. 5, n. 1, p. 1-10, 2017. 
GUIDOTTI, V.; PINTO, L. F. G.; DE BARROS FERRAZ, S. F.; SANTIN, P. H.; BRANCALION, G. S.; DE BARROS FERRAZ, S. F. Código Florestal: contribuições para a regulamentação dos programas de regularização ambiental (PRA). Sustentabilidade em Debate, v. 4, n. 1, p. 1-12, 2016.

METZGER, J. P. O Código Florestal tem base científica? Natureza \& Conservação, v. 8, n. 1, p. $1-5,2010$.

MINAS GERAIS INSTITUTE OF WATER MANAGEMENT. Resumo Executivo do Plano Diretor de Recursos Hídricos da Bacia do Rio Verde. Belo Horizonte: IGAM, 2010. $75 \mathrm{p}$.

MONTEIRO, M. E. C.; DE ALCÂNTARA LAUDARES, S. S.; LEITE, L. H.; MORAS FILHO, L. O.; BORGES, L. A. C. Cenários de preservação com a aplicação do novo código florestal: estudo em uma bacia hidrográfica na Serra da Mantiqueira. Caminhos de Geografia, v.18, n. 64, p. 185-198, 2017.

PINTO, E. D. A.; AZAMBUJA, A. D.; FARIAS, J. A. M.; SAlGUEIRO, J. D. B.; PICKBRENNER, K. Atlas pluviométrico do Brasil: isoietas mensais, isoietas trimestrais, isoietas anuais, meses mais secos, meses mais chuvosos, trimestres mais secos, trimestres mais chuvosos. Brasília: CPRM, 2011.

PUSEY, B. J.; ARTHINGTON, A. H. Importance of the riparian zone to the conservation and management of freshwater fish: a review. Marine and freshwater Research, v. 54, n. 1, p. 1-16, 2003. https://doi.org/10.1071/MF02041

RODRÍGUEZ-ROMERO, A. J.; RICO-SÁNCHEZ, A. E.; MENDOZA-MARTÍNEZ, E.; GÓMEZ-RUIZ, A.; SEDEÑO-DÍAZ, J. E.; LÓPEZ-LÓPEZ, E. Impact of Changes of Land Use on Water Quality, from Tropical Forest to Anthropogenic Occupation: A Multivariate Approach. Water, v. 10, n. 11, 1518, 2018. https://www.mdpi.com/20734441/10/11/1518\#

ROSOT, M. A. D.; MARAN, J. C.; DA LUZ, N. B.; GARRASTAZÚ, M. C.; DE OLIVEIRA, Y. M. M.; FRANCISCON, L.; CLERICI, N.; VOGT, P. DE FREITAS, J. V. Riparian forest corridors: A prioritization analysis to the Landscape Sample Units of the Brazilian National Forest Inventory Riparian forest corridors: A prioritization analysis to the Landscape Sample Units of the Brazilian National Forest Inventory. Ecological indicators, v. 93, p. 501-511, 2018. https://doi.org/10.1016/j.ecolind.2018.03.071

OLIVEIRA-FILHO, A. T.; JARENKOW, J. A.; RODAL, M. J. N. Floristic relationships of seasonally dry forests of eastern South America based on tree species distribution patterns. In: PENNINGTON, R. T.; LEWIS, G. P.; RATTER, J. (eds.). Neotropical savannas and seasonally dry forests: plant diversity, biogeography, and conservation. Oxford: Taylor \& Francis CRC Press, 2006. p. 59-192.

SOARES-FILHO, B.; RAJÃO, R.; MACEDO, M.; CARNEIRO, A.; COSTA, W.; COE, M.; RODRIGUES, H.; ALENCAR, A. Cracking Brazil's forest code. Science, v. 344, n. 6182, p. 363-364, 2014. https://dx.doi.org/10.1126/science. 1246663

SPAROVEK, G.; REYDON, B. P.; PINTO, L. F. G.; FARIA, V.; DE FREITAS, F. L. M.; AZEVEDO-RAMOS, C.; GARDNER T.; HAMAMURAG, C.; RAJÃO, R.; CERIGNONIC, F.; SIQUEIRA, G. P.; CARVALHO, T.; ALENCAR, A.; RIBEIRO, V. Who owns Brazilian lands? Land Use Policy, v. 87, 104062, 2019. https://doi.org/10.1016/j.landusepol.2019.104062 
VALERA, C. A.; PISSARRA, T. C. T.; MARTINS FILHO, M. V.; VALLE JÚNIOR, R. F.; OLIVEIRA, C. F.; MOURA, J. P.; SANCHES FERNANDES, L. F.; PACHECO, F. A. L. The Buffer Capacity of Riparian Vegetation to Control Water Quality in Anthropogenic Catchments from a Legally Protected Area: A Critical View over the Brazilian New Forest Code. Water, v. 11, n. 3, p. 549, 2019. https://doi.org/10.3390/w11030549

VIOLA, M. R.; MELLO, C. R.; BESKOW, S.; NORTON, L. D. Impacts of Land-use Changes on the Hydrology of the Grande River Basin Headwaters, Southeastern Brazil. Water Resources Management, v. 28, n. 13, p. 4537-4550, 2014. https://doi.org/10.1007/s11269-014-0749-1

ZAIMES, G. N.; TUFEKCIOGLU, M.; SCHULTZ, R. C. Riparian Land-Use Impacts on Stream Bank and Gully Erosion in Agricultural Watersheds: What We Have Learned. Water, v. 11, n. 7, p. 1343, 2019. https://doi.org/10.3390/w11071343 